\title{
A VOZ DOS BANDOS: COLECTIVOS DE JUSTIÇA E RITOS DA PALAVRA PORTUGUESA EM TIMOR-LESTE COLONIAL*
}

Ricardo Roque

\section{Introdução}

Este ensaio explora as relações entre o discurso da justiça e a prática do ritual no governo colonial português em Timor Leste, entre a segunda metade do século XIX e as primeiras décadas do século XX. O objecto de análise é uma instituição singular do governo colonial neste pequeno território, onde os portugueses se encontravam estabelecidos desde longa data. ${ }^{1}$ Refiro-me ao complexo designado por bandos, as ordens e as instruções de comando emanadas pelo governador português em Díli para as populações dos diversos reinos timorenses dispersos pelo país. Aimportância do discurso no desenho de relações coloniais de poder e, bem assim, em contraponto, de relações de resistência ou subversão a esse poder - tem constituído um tema central na antropologia e nos estudos do colonialismo. ${ }^{2}$ Contudo, a dominância de definições estritamente linguísticas ou literárias do objecto de análise neste campo de estudos tem deixado na sombra um importante aspecto das formações discursivas do colonialismo, a saber, a inscrição material e ritual dos discursos coloniais, sem a qual a força política da linguagem dificilmente se compreende. ${ }^{3}$

Nos estudos pós-coloniais, em especial, vêm imperando abordagens que, na esteira de autores como Edward Said ou Homi Bhabha, tendem a restringir o estudo da palavra colonial às manifestações internas às estruturas literárias, retóricas e linguísticas dos textos (cf. Said 1978; Bhabha 1994). ${ }^{4}$ O textualismo destas análises do discurso colonial, como bem observou Robert J. C. Young, falha em não considerar as materialidades do discurso e, logo, do próprio colonialismo (Young 2002:408-410; cf. O'Hanlon \& Washbrook 1992; Parry 2004). Paradoxalmente, porém, este foi um aspecto central do fecundo trabalho de Michel Foucault, autor que serviu de principal inspiração à vaga de estudos sobre discurso na crítica pós-colonial. ${ }^{5}$

Este texto explora o tema do discurso colonial em contraponto a essas tendências, procurando devolver materialidade às palavras coloniais asso- 
ciadas ao exercício do poder e do governo no domínio político-jural. Propõe uma etnografia histórica da linguagem colonial, partindo da hipótese de que a compreensão do poder da linguagem e da linguagem do poder se situa no imbricamento entre palavras e coisas e, em especial, no encontro entre rito e discurso na prática material. Tendo como referência a colónia portuguesa de Timor-Leste, irei explorar a força de lei das palavras enquanto parte integral do que designarei por colectivos de justiça, isto é, arranjos heterogéneos de pessoas, coisas e palavras, nos quais elementos linguísticos e não linguísticos se entrelaçam nos gestos e nas matérias do ritual com o fim estratégico de produzir a ordem nos assuntos jurais: comunicando instruções, impondo normas, conciliando conflitos, punindo transgressões, exercendo comando e garantindo a obediência das populações.

Por conseguinte, não se poderá perceber a força, ou a fraqueza, dos ditos coloniais de governo neste domínio sem relacioná-los com as circunstâncias sociomateriais e os regimes litúrgicos de exercício da palavra, vigentes em cada situação colonial. Esta perspectiva, de orientação performativa - e, assim, tendo precedentes nas seminais propostas conceptuais de J. L. Austin, na filosofia da linguagem, e de Stanley Tambiah, na antropologia do ritual (cf. Austin 1962; Tambiah 1985) — fornece uma alternativa às limitações das análises pós-coloniais do discurso enquanto entidade estritamente linguística e textual, incorpórea e abstracta.

Com efeito, a crítica literária e pós-colonial tende a padecer do enganoso pressuposto da independência linguística da palavra em relação às suas condições sociais, rituais e materiais de existência. Do ponto de vista da história, da sociologia e da antropologia, este pressuposto elimina do horizonte de análise a questão do que significa dizer - e dizer com que significados e consequências sociopolíticas - palavras portuguesas em distintos espaços e momentos da história colonial e pós-colonial. Endereçar esta questão, inspirando-nos em Austin, implica considerar que a força realizadora das palavras coloniais proferidas é indissociável da sua inscrição em "circunstâncias apropriadas", incluindo a articulação adequada das coisas ditas com outras coisas feitas, verbais ou não verbais (Austin 1962:8). Como acrescentou ainda Pierre Bourdieu, esta é uma questão que não se resolve procurando "o poder das palavras nas palavras"; não se resolve considerando as palavras em si mesmas. Resolve-se, antes, focando os modos como são ditas e examinando as condições que lhes permitem adquirir autoridade e eficácia performativas. "A questão ingénua do poder das palavras", observou Bourdieu, "está logicamente implicada na supressão inicial da questão dos usos da linguagem, logo, das condições sociais de utilização das palavras" (Bourdieu 1982:103). ${ }^{6}$ 
Desta forma, a meu ver, reconverter em objecto operacional da antropologia histórica o constructo discurso da crítica pós-colonial obriga a uma ruptura epistemológica com a visão ilusoriamente linguística da palavra que lhes subjaz, e ao redireccionamento da pesquisa para as circunstâncias, os modos e os regimes de praticar a palavra colonial. Este ensaio procura, assim, contribuir para libertar a investigação do colonialismo - em especial, do colonialismo português - desse tipo de pressupostos, enfatizando a condição da palavra enquanto sonoridade colonial inscrita nas materialidades de regimes cerimoniais de poder. Em foco estão as seguintes interrogações gerais: Quais as condições práticas através das quais o discurso colonial, em português, se realizou enquanto discurso de poder, de lei, e de justiça, nos vários tempos e lugares da colonização portuguesa? Que articulações sociomateriais possibilitaram aos administradores portugueses uma linguagem de governo que, em situação, garantisse eficácia à relação governativa com as sociedades nativas? E, por fim, de que modo o poder de que se investia o discurso colonial, bem como as matérias de que se rodeava foram apropriados por agentes indígenas para proveito próprio?

Abordarei estas questões gerais a partir do estudo dos modos rituais do exercício da palavra portuguesa, em contexto de administração jural, condução da guerra e, em geral, de governação dos povos, em Timor Leste. O arco cronológico do estudo abrange o período que vai do início de 1860 (assinalado pela administração reformista do governador Afonso de Castro) aos anos de 1911-13, datas da grande sublevação de Manufahi que abalou o regime português na ilha e à qual se seguiu revisão da importância atribuída aos reis e reinos indígenas. Concentrarei a atenção nos actos de comando e criação de lei da administração colonial, denominados por bandos, e estenderei o meu olhar às suas apropriações timorenses. Irei sugerir que, nas composições formadas pelos bandos coloniais, a linguagem portuguesa adquiria a qualidade de "linguagem de instituição" (cf. Bourdieu 1982:103); de um discurso investido de autoridade legal e justiceira, possuidor de uma potência performativa, realizadora, pela qual os portugueses intervinham efectivamente na vida das populações locais. Nestes contextos, a palavra portuguesa não extraía a sua energia de relações entre signos contidas na estrutura-língua em que se movia. Ao invés, extraía a sua força de terror e de verdade da natureza litúrgica dos colectivos em que se inscrevia.

Esta rede sociolinguística da voz da justiça colonial envolvia, como veremos, mecanismos simbólicos de delegação da palavra do governador a porta-vozes executivos (por regra, oficiais do exército). Porém, como também procurarei sugerir, estes mecanismos simbólicos não bastam para dar conta do funcionamento dessa rede; é preciso atender aos seus constituintes socio- 
materiais e à sua capacidade performativa. Nos bandos coloniais, conforme argumentarei, as ordens do governo constituíam muito mais do que uma enunciação linguística no sentido convencional, muito mais do que simples fluxos de informação. Formavam um dispositivo sociomaterial fortemente codificado. A voz de comando e ordem do governador só poderia ser capaz de actuar, de facto, sobre as populações mediante inserção num colectivo de coisas, gestos, corpos e palavras, estilizado na forma de uma tecnologia litúrgica. A sua eficácia ritual pressupunha a presença de "média múltiplos", para tomar de empréstimo um termo de Tambiah (cf. Tambiah 1985:128), mediadores verbais e não verbais através dos quais se acionava material e simbolicamente a liturgia.

Estudar o discurso colonial a partir dos bandos de Timor implica, pois, operacionalizá-lo enquanto evento da prática ritual do governo, evento manifesto em dispositivos sociomateriais no qual coisas, palavras e pessoas se arranjam para, em conjunto, gerar no mundo determinados efeitos de poder, de lei, e de justiça. A noção de colectivos de justiça visa dar conta destas dimensões. Inspiro-me no conceito de collectif, com o qual Law e Callon pretenderam descrever a acção sociológica enquanto produto de associações heterogéneas entre entidades humanas e não humanas (Callon \& Law 1995). Por conseguinte, entendo aqui os bandos não na estrita qualidade linguística de "discurso", mas sim na qualidade alargada de discurso enquanto colectivo, isto é, enquanto arranjo linguístico e sociomaterial composto por elementos variados, capaz de atuar, em rede, na produção de efeitos de poder e de verdade. A adopção desta perspectiva alargada sobre o discurso colonial é ainda importante na medida em que as apropriações timorenses dessa significativa instituição justiceira tenderam a extrair dos bandos a sua substância performativa de acto litúrgico de lei em detrimento da apropriação das suas sonoridades linguísticas. Era delegada na agência de objectos que a voz de comando dos chefes timorenses se assinalava e se ouvia pelo mundo. Nas suas variantes timorenses, atendendo ao que ficou registrado nos documentos portugueses, bandus formariam, pois, colectivos dominantemente não linguísticos de justiça, nos quais imperavam coisas silentes, em lugar de enredos de enunciações faladas.

O texto está estruturado em quatro partes. Começo por explorar os mecanismos coloniais de delegação e de constituição de porta-vozes do governador português, no contexto do sistema administrativo em Timor. Passo depois para uma análise dos bandos do governador enquanto instituição ritual e colectivo de comando, incluindo um exame da sua função justiceira na produção de efeitos de conciliação e de castigo no mundo timorense. Por fim, abordo o original significado que os bandos vieram a adquirir no 
contexto das suas utilizações pelas principais autoridades jurais timorenses, os liurais, ${ }^{7}$ designados reis pela administração portuguesa.

\section{A voz do governador e os círculos de delegação}

O Governador é para os indígenas o grande justiceiro, o general, o único representante de Sua Majestade, o pai, os oficiais são os seus delegados, os seus braços, o governador fala-lhes pela boca deles, o que eles dizem e preceituam é o que diz e preceitua o governador (Silva para MSNMU 13 Julho 1905; itálicos no original).

Nesta passagem de 1905, o governador de Timor, José Celestino da Silva, expunha aos seus superiores no Ministério da Marinha e Ultramar a sua interpretação sobre a interpretação nativa acerca do funcionamento da justiça e do comando político português em Timor. Decerto esta descrição, ao elidir as muitas fragilidades da autoridade do governador em Díli, projeta um imaginário colonial de poder incontestado, consensual e absoluto que dificilmente encontrava eco na realidade. Não obstante, ela expressa também temas importantes das concepções nativas sobre o exercício do poder e o sistema político nesta área do Sudeste asiático, concepções em que o sistema colonial português em Timor se achava, então, parcialmente absorvido. ${ }^{8} \mathrm{Um}$ governante, posicionado ao centro, imóvel, silencioso e supremo, irradia o seu poder na forma de uma força carismática recebida de fontes sacralizadas e invisíveis, exercendo comando efectivo sobre os seus domínios vassalos através da acção dos seus delegados e porta-vozes executivos. ${ }^{9}$

O princípio da delegação simbólica do poder desenhava em torno do governador, em Díli, uma estrutura concêntrica de administração, constituindo-se como um dos principais mecanismos de acção governativa. Nesta interpretação colonial, o governador — designado em língua tétum como embóote (expressão tétum para "pessoa maior"), ou também concebido de acordo com os dualismos simbólicos nativos ("pai", ou "pai e mãe") — emergia como fazedor derradeiro e definitivo da justiça, no centro do mundo jurídico e político. Ele era o possuidor magnético do poder criativo e conciliador da ordem, bem como do poder terrífico da justiça rígida e implacável. A sua voz era ordem e comando. Contudo, para lá de Díli, o seu poder apenas imanava e a sua voz unicamente se escutava através dos seus delegados executivos: os oficiais.

Esta metáfora colonial do governo, refractada nas interpretações nativas, tinha implicações concretas no desempenho da administração portuguesa 
da segunda metade do século XIX. Em Timor-Leste, o papel de porta-vozes e executores da palavra do governo era desempenhado por militares, oficiais europeus do exército que assumiam funções na guerra e na administração dos distritos no interior. Eram eles os executantes da justiça e da lei colonial, estando à cabeça dos distritos ou dos comandos militares em que se dividia a administração do território. Longe, em terras distantes, transmitiam a voz do governador, as palavras de comando que nomeavam o mundo, conduziam a acção das populações e regulavam a boa ordem. A imagem do grande justiceiro emitindo a sua voz a partir de um centro e exercendo comando sobre as populações através dos seus braços, os oficiais, era parte integrante do modelo militar de administração seguido em Timor desde, pelo menos, a década de 1860 - e, possivelmente, desde tempos mais antigos.

Desenhado e desenvolvido por Celestino da Silva, o modelo, em parte, já havia sido visionado pelo seu antecessor, Cipriano Forjaz, e as suas origens históricas mais imediatas encontravam-se na importante reforma administrativa do território feita por Afonso de Castro em 1859-63. Já antes de 1860, segundo o mesmo Afonso de Castro, os militares representavam o governo perante as autoridades timorenses na qualidade de "Comandantes dos Reinos". A primazia dos militares e as suas responsabilidades políticojurais foram ampliadas e formalizadas por Castro, em 1863. Castro sobrepôs então à divisão indígena em reinos uma divisão do território em Distritos, encabeçados por "Comandantes dos Distritos", militares portugueses que detinham extensas atribuições administrativas e judiciais em representação do governador (Castro para MSNMU, 4 Abril 1863; ver também Castro 1867).

Nas décadas seguintes, os oficiais do exército de Portugal viram estas suas atribuições formalizadas e expandidas (cf. Roque 2011a). A reforma administrativa promovida por Celestino da Silva entre 1896 e 1898 foi outro momento marcante desse processo. Em 1896, no seguimento da Autonomia Administrativa concedida a Timor pela metrópole (por fim, separando-se da tutela do governo de Macau), Celestino da Silva voltou a dividir a colónia em "comandos militares", dirigidos por oficiais do exército português. O governador alegava então que estava apenas a pôr no papel uma prática rotineira, antiga e eficiente da administração portuguesa na colónia, com isso garantindo adicional legitimidade ao sistema tradicionalmente estabelecido para levar até os reinos timorenses o peso da voz justiceira do governo (Silva para MSNMU 11 Jan. 1898).

A metáfora do governador e seus delegados evocada por Celestino da Silva incluía apenas os militares europeus, e é possível que, no período em análise, os oficiais portugueses fossem considerados, em geral, como principais executivos do governador. Todavia, na prática, a legitimidade do exercício desses poderes encontrava-se bem mais espalhada e fragmentada 
pelo mundo indígena. Em potência, o círculo de delegados da voz do governador integrava ainda as autoridades nativas consagradas pelos portugueses com o título de rei (e outros títulos, como Dom e coronel) e, bem assim, por via de mecanismo homólogo de delegação concêntrica, pelos delegados do rei. Durante cerimónias de vassalagem e investidura celebradas desde pelo menos o século XVII, os governadores portugueses empossavam os liurais timorenses de poderes no domínio da justiça, atribuindo-lhes títulos de nobreza e altas patentes militares.

Por essa via, o papel de delegados executivos do poder político-judicial português ficava disperso pelos reis timorenses, que encabeçavam a miríade de reinos nativos em que se repartia o país de Timor Leste, até bem dentro do século XX (Roque 2011b). Os liurais cerimoniosamente investidos com o título de reis pelos portugueses podiam assim usar a legitimidade de delegados das forças jurais provindas de Díli para exercer justiça indígena nos reinos timorenses. Por conseguinte, por intermédio da vassalagem, reis e liurais podiam falar e fazer lei em nome de poderes jurais de natureza e origem idênticas às dos militares europeus, a ponto de se constituírem em fonte de poder justiceiro independente do governador. Este é um importante ponto a reter, pois é no quadro deste duplo circuito de delegação da autoridade jural que se situam os bandos, quer nas suas expressões coloniais, quer, como adiante veremos também, nas suas variantes indígenas.

Estes dois círculos coexistentes de delegados (oficiais e reis) eram, contudo, objecto de referências e valorizações bem distintas no discurso e na organização formais da administração. Os governadores estavam cientes da duplicidade do sistema de delegação, no qual comparticipavam, de forma muitas vezes tensa, autoridades nativas e autoridades europeias. A organização administrativa da segunda metade de Oitocentos insistia, como vimos, nos poderes de exercício da justiça delegados aos militares portugueses, com o objectivo de restringir a estes o monopólio da palavra legítima do governo. Porém, embora os governadores desse período (incluindo Celestino da Silva) lamentassem a centralidade e a influência dos régulos timorenses, não se dariam passos determinantes para as eliminar, até pelo menos 1912-13. Em vez disso, envidou-se por reformas do sistema de delegação que reforçavam a importância formal dos oficiais portugueses deixando, actuante na sombra, a poderosa autoridade jural dos liurais, a um tempo correlativa e concorrente dos militares.

A regulação dos assuntos seculares era uma área de circunscrição legítima do comando do governador. A comunicação desse comando, de Díli para os reinos, dependia da estrutura concêntrica de delegação aos oficiais e esta, por seu lado, da adequada expressão performativa da representação que 
era delegada. As condições de eficácia desta representação da autoridade e da comunicação do comando eram, portanto, de natureza ritual e simbólica. A eficácia e a legitimidade da autoridade colonial encontravam-se estritamente ligadas à capacidade de os oficiais e governadores portugueses reproduzirem regras de etiqueta e códigos cerimoniais de conduta que os locais entendiam ser obrigatórios, porque prescritos por tradição. A gestão correcta deste cerimonialismo era de imensa importância para o governo colonial, inclusive, e em especial, nas relações com as autoridades timorenses (Roque 2012). Por conseguinte, a execução da justiça, a deferência pública para com os representantes da autoridade e a transmissão de instruções emitidas pelo governador constituíam significativos momentos administrativos.

No relacionamento com as sociedades timorenses, a comunicação de instruções pelo governador chegava aos reinos na forma, no som e na atmosfera de um acto cerimonial, verdadeiramente litúrgico. Nos reinos, jamais as palavras do governador eram apenas palavras. Constituíam um colectivo cerimonial heterogéneo, de eficácia e geometria variáveis (todavia, fortemente codificado), designado por bandos. Palavras portuguesas vindas de Díli, enfim, jamais se manifestavam como mero evento linguístico. Pelo contrário: configuravam um acontecimento que, tendo em vista a produção de efeitos de poder, reunia muito mais do que sons, palavras e informação. Reunia também materialidades: coisas investidas de especial autoridade (tambores, bandeiras, espingardas, papéis) e pessoas investidas da força de porta-vozes (oficiais e delegados), ou da de guardiões das coisas e dos portavozes (soldados). Nesta composição consistiam os bandos, que eram, nessa condição colectiva, a palavra do governo, a voz do governador; e que eram apenas nessa condição, enfim, "discurso colonial". Tratemos agora, mais de perto, a constituição destes colectivos e os efeitos que pretendiam gerar.

\section{Ritos de lei e colectivos de comando ${ }^{10}$}

A palavra portuguesa bando possuía, desde o século XVIII, um conteúdo marcado pela conexão com o exercício do poder e, em particular, com a condução da guerra e a produção ritualista do discurso de autoridade jurídico-legal. Originário da antiga expressão germânica bam (significando pregão), o termo português preservava esse sentido primeiro, reforçado com a ideia de um comando autoritário e de uma "proibição" (Machado 1989:384). Bandos designavam ainda "anúncios públicos" e actos com força de lei proclamados ao som do tambor. Possuíam, assim, em português, uma etimologia marcada igualmente por uma origem marcial. Segundo o 
referencial dicionário do início do século XVIII, o Vocabulário portuguez e latino do padre Raphael Bluteau, a expressão "publicar por bando" aludia a "quando se declara publicamente um decreto, uma lei". "Entre nós", registava ainda Bluteau, "Bando é pregão de guerra, a som de caixa, com pena imposta aos transgressores de alguma lei militar; [...] os Bandos serão só as coisas pertencentes à ordem da guerra" (Bluteau 1712-1728:31).

O Dicionário da língua portuguesa, de António de Morais Silva, registava, em 1813, um significado semelhante — "pregão público, pelo qual se faz pública alguma ordem ou decreto; e se denuncia talvez guerra" - suplementando-o com uma hipotética genealogia da palavra no termo basco Bandoa, significando édito (Silva 1813:259). ${ }^{11}$ Ainda que estas etimologias de bando pareçam especificá-lo pela liturgia marcial dos gestos e dos sons que envolviam a execução, o vínculo assinalado entre bando e édito é igualmente significativo, pois ambas as formas apontam para a ordem ritual e performativa do discurso do poder, com referência a práticas públicas de anúncio e imposição das palavras de autoridade.

Essa antiga significação portuguesa - de ritualizada proclamação pública, marcial nos contornos, com força de lei - manteve-se efectiva nos usos coloniais e jurídicos de Timor ao longo do século XIX e nas primeiras décadas do século XX.$^{12}$ Provavelmente, então, uma antiga forma - praticada em cenário quer colonial, quer metropolitano - de comunicar ordens em situação militar, ou de transmitir a palavra de lei dos governantes à população, a expressão bandos continuava a aparecer, em Macau e Timor, na linguagem oficial da administração colonial portuguesa Oitocentista, convocando o seu sentido original de proclamação com suprema autoridade, executada na figura marcial de um rito de lei, emanada da autoridade governamental.

Em 1879, por exemplo, o acto oficial de investidura de Joaquim José da Graça como Governador da Província de Macau e Timor apareceu registado no Boletim Oficial da Província sob o título de bando, após tal investidura ter sido proclamada nas ruas de Macau, "publicado nos lugares de estilo ao som de caixa [tambor]" (Anónimo 1879:289; itálicos no original).$^{13} \mathrm{O}$ termo bando, portanto, quer nos seus sentidos etimológicos, quer nos seus usos administrativos, parecia evocar na Ásia portuguesa de Oitocentos não só a ideia de um mandamento superior emitido da boca, ou da pena, do governador, como também o de um conjunto de gestos codificados, uma ocasião cerimonial, na qual palavras, coisas e pessoas se interligavam na produção de um pretendido efeito de autoridade.

Em Timor Leste, este significado vernacular encontrava-se basicamente preservado nos usos dos agentes coloniais. Prosseguindo com a metáfora de Celestino da Silva, o governador falava aos timorenses através da boca 
dos seus oficiais executivos. Todavia, a sua voz apenas adquiria eficácia na condição de ser proferida num quadro litúrgico preestabelecido, e na condição, também, de não ser simplesmente "voz", mas sim um composto heterogéneo, em que palavras, sons, pessoas, e objectos materiais específicos pareciam actuar combinadamente na produção de um mesmo efeito. ${ }^{14}$ Os bandos representavam estas condições e este colectivo. A um tempo instituição de comunicação e de governo, faziam a presença do governador acontecer nos assuntos ligados aos reinos timorenses. Bandos aconteciam como uma acção litúrgica de leitura, em voz alta, de uma ordem do governador, acompanhada ao som do tambor.

Os bandos portugueses eram, assim, em especial, as ordenações e os actos de autoridade do governador que tomavam como objecto, quase exclusivamente, a regulação da ordem nos reinos timorenses e, em particular, a regulação das relações do governo com as classes aristocráticas nativas. O termo (bem como a gestualidade e a materialidade de rituais a ele ligadas) havia adquirido uma importante associação ao tipo de governo, autoridade e justiça reclamado pelos governadores e militares portugueses. "Publicar" ou "proclamar" um bando era a expressão usada pelos portugueses em Timor para denotar a emissão efectiva da lei colonial portuguesa no mundo timorense, a comunicação das instruções do governador, de Díli para os reinos. O carácter ritualizado dos bandos era central às suas definição e efectividade. Apenas sob circunstâncias codificadas poderia um bando escrito e emitido pelo governador no seu palácio, em Díli, vir a ser respeitado e obedecido pelos seus destinatários nativos, nos reinos. Estas eram condições necessárias, mas, como veremos, não suficientes de obediência à voz do governo.

$\mathrm{O}$ acto de pronunciamento de um bando devia seguir o estilo (isto é, o preceito ritual e costumeiro, estabelecido por tradição). Um grupo de soldados (portugueses; timorenses; ou portugueses e timorenses), liderado por um oficial do exército português e acompanhado de "caixa e bandeira", tinha a função de "publicar o bando", servindo o oficial de porta-voz do governador (Figura 1). Viajando até o reino em questão, abeirando-se das povoações, ou na presença das autoridades locais, os emissários do governador liam em voz alta, publicamente, o bando escrito pelo governador "em papel de grande formato, e com o selo de fitas pendentes", enquanto rufava o tambor e se tomava a companhia da bandeira portuguesa: "O aparato, às vezes mais que a decisão" - escreveria o capitão Hélio Felgas, referindo-se em 1956 a essas antigas cerimónias de leitura em Timor — " chegava, em certos casos, para congraçar os ânimos" (Felgas 1956:267). Era este arranjo ritualizado de coisas, gestos e sonoridades que, em acção, forneciam às palavras portuguesas do governador as suas condições de eficácia discursiva e, logo, de poder. 
Figura 1: Oficiais do exército português com tropas de segunda linha (moradores), apresentando "caixa e bandeira", após uma campanha punitiva c. 1900. Prisioneiros de guerra são também mostrados (embaixo, à direita).

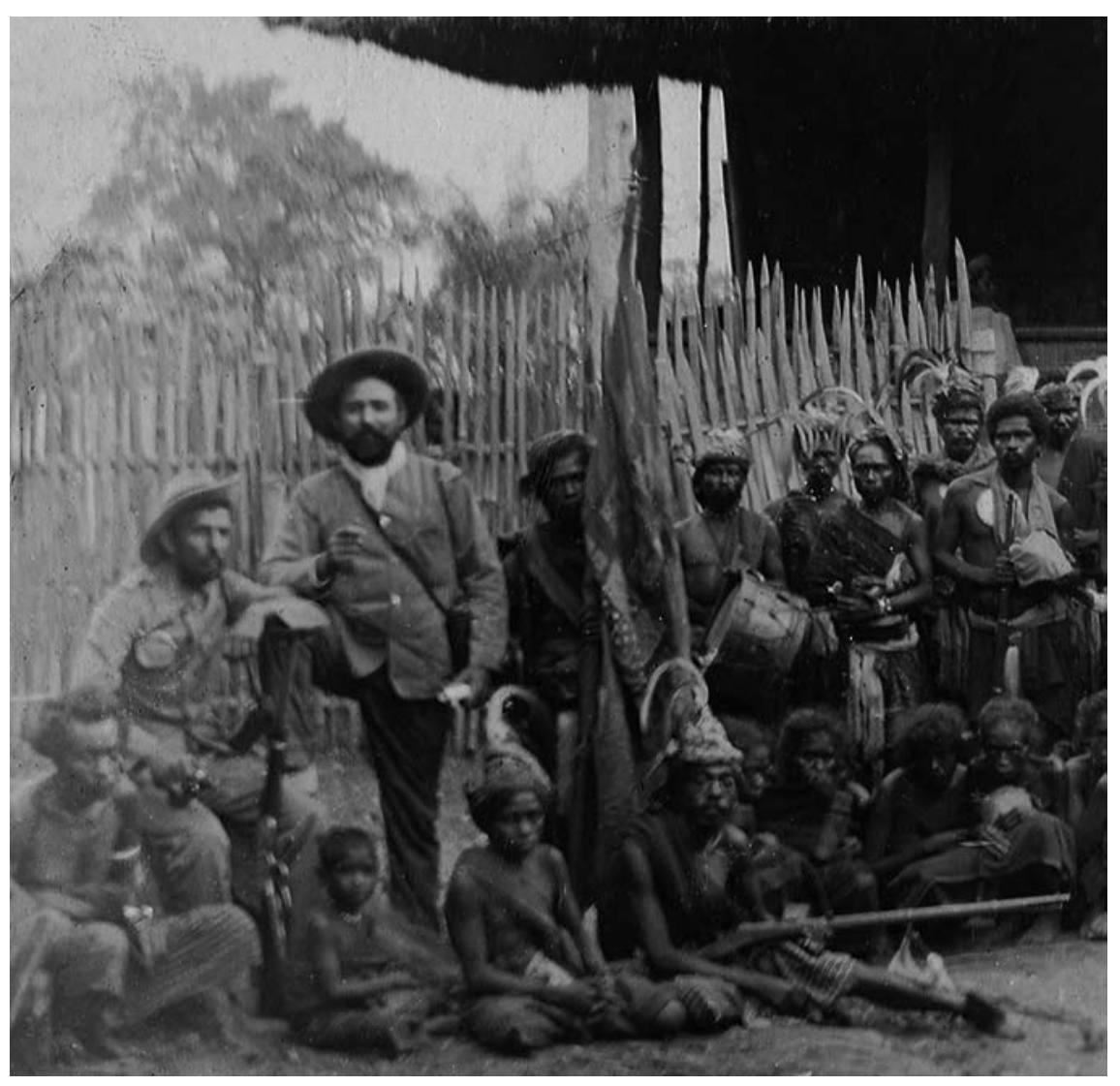

Fonte: Álbum de fotos do tenente Carlos Leitão Bandeira. Cortesia de António Bandeira

O acto de proclamação, por norma, estava a cargo da voz dos oficiais executivos portugueses. Por vezes, porém, falantes timorenses eram mobilizados enquanto "intérpretes" ou tradutores para secundar a força do governo. Com efeito, no seu sentido linguístico mais estrito, os bandos consistiam em instruções escritas em português, as quais, no acto de proclamação, podiam ser traduzidas e oralizadas para o Tétum (a língua franca de Timor), ou para outra língua indígena. Mantendo os elementos do cenário ritual, estes intérpretes desmontavam a lusofonia da voz do governador e de seus oficiais para a fazer reaparecer num dos múltiplos dialectos ou línguas locais. Puramente lusófona, portanto, nunca ou raramente chegava a voz do 
governador ao ouvido dos timorenses. Em algumas ocasiões, além disso, os delegados nativos da autoridade do governo, os reis, podiam eles próprios proclamar bandos em nome do governador. Mais: conforme veremos adiante, nos bandos traduzidos em instituição timorense de comando jural a própria palavra parecia apagar-se do colectivo.

Retomarei estas apropriações indígenas mais à frente. Interessa-me explorar, agora, o sentido colonial em que estas apropriações originalmente radicavam e no qual, simultaneamente, se fundava o poder colonial português. Mantenhamos o foco, então, nos bandos como instituição da lei e da palavra do governador. Os bandos tornavam a voz do grande justiceiro audível, ainda que episodicamente, por todo o território. Com o seu anúncio, podiam chegar a paz e a reconciliação — mas também a guerra e o terror. Atentemos às circunstâncias típicas em que eram mobilizados e aos modos como o seu exercício servia à regulação da ordem de duas formas principais: a conciliação - e o castigo.

\section{Bandos coloniais, guerra e paz}

Os bandos eram original e fundamentalmente uma emanação do governador português, utilizada para comunicar às populações dos reinos timorenses e, em especial, às classes aristocráticas todo tipo de determinação, ordem, apelo, punição ou proibição deliberada pelo governador. Os bandos ofereciam palavras de ordem em circunstâncias relativamente variadas, mas um traço comum era o facto de a desobediência ou a transgressão às ordens emitidas implicar uma consequência punitiva. No centro das circunstâncias típicas em que os bandos tinham lugar estava a ligação às obrigações tributárias e de subordinação cerimonial dos timorenses para com o governo. Bandos eram usados, assim, para accionar ou para instituir os mecanismos tributários da vassalagem. Esses tributos incluíam maneiras variadas de "impostos" (nomeadamente a finta), mas também tributos na forma de força braçal, enquanto trabalhadores ou guerreiros.

Era costumeiro, por exemplo, o recurso a bandos para chamar os timorenses a seguirem o partido do governo na guerra, cumprindo tributo como guerreiros na qualidade de arraiais; ou para colaborar com o governo nas "obras públicas" como trabalhadores (por exemplo, na construção de um edifício do comando militar). Assim, muito embora uma das suas funções, conforme assinalou Hélio Felgas, consistisse na resolução de conflitos entre reinos ou linhagens nobres timorenses, o âmbito de actuação dos bandos do governador era bem mais amplo (cf. Felgas 1956:267). Em 1868, por 
exemplo, na preparação da guerra contra o reino de Cová (da qual o partido português viria a sair derrotado), o governador Francisco Teixeira da Silva proferiu o seguinte bando, lido e proclamado pelos seus executivos através do território, contendo uma convocatória marcial dos "vassalos" de Portugal contra os "rebeldes" de Cová:

Há quatro anos um bando de rebeldes, fortificados na povoação de Cová, enxovalha a gloriosa bandeira das quinas. Isto não pode continuar assim. Vou marchar para Batugadé, levarei o batalhão de linha. Que me acompanhem os verdadeiros vassalos da coroa de Portugal! Que nos sigam todos aqueles que querem ser portugueses, na certeza de que vamos marchar para a vitória! (Teixeira da Silva apud Castro 1944:79).

O bando de Teixeira da Silva chamava os vassalos de Portugal à guerra. Em Timor, os soldados regulares mal chegavam, nesse período, às duas centenas, nos melhores momentos. Assim, por mero efeito de uma voz inserta num colectivo marcial de soldados, oficiais, e caixa e bandeira, o governador esperava resolver essa fragilidade crónica, mobilizando guerreiros nativos. Bandos serviam, então, para "chamar à obediência", instruindo os reinos amigos a cumprirem as suas obrigações tributárias estabelecidas pela vassalagem; ou ordenando reinos revoltosos a não se desviarem de uma condição submissa de vassalos.

A liturgia dos bandos cumpria ainda outras importantes funções performativas. Servia para nomear e instituir o real, organizando em particular a distribuição e a hierarquização de poder, status e autoridade política e militar no interior das sociedades timorenses. Podiam servir assim para reinstituir, ou para destituir, a principal autoridade jural timorense, o rei ou liurai, das honras e dos poderes de que se achava investida, por via da vassalagem. Em 1880, por exemplo, o comandante de Manatuto, alferes Cândido António da Silva, foi incumbido de pronunciar um bando emitido pelo governador Hugo de Lacerda, no qual, alegando-se a "rebeldia" do rei de Laleia, se determinava "a destituição de todas as honras e jurisdições do criminoso [rei] e a sua captura, prometendo-se recompensa a quem o prendesse e castigo a quem dalgum modo lhe desse protecção ou abrigo" (Governo de Timor, 26 Fev. 1880). Do mesmo modo, um ano depois, em 1881, outro governador, Cardoso de Carvalho, ordenou por meio de bando a restauração da paz e a reposição da autoridade do mesmo régulo de Laleia: "Que um bando composto por caixa e bandeira", escrevia-se na portaria governamental, "dê a maior publicidade no reino de Laleia à presente portaria, ordenando aos povos que reconstruam as suas antigas povoações e se entreguem à 
vida pacífica, cultivando as suas várzeas e mais terrenos que sempre lhes pertenceram" (Carvalho, Portaria 1 Março 1881).

Os bandos existiam, sobretudo, em forte relação com duas funções opostas, mas complementares - de acção justiceira do governador e de seus delegados: a conciliação e o castigo. A distinção existente no imaginário colonial entre "bandos de paz" e "bandos de guerra" expressava esta dupla função de governo. O governador — e, mediante a lógica da delegação, também os seus oficiais - podia ser chamado pelos agentes timorenses para, através de bandos, promover a (re)conciliação, actuando como supremo árbitro das disputas entre timorenses, muito em especial quando estas envolviam a realeza e a aristocracia nativas. Ao mesmo tempo, do governador era também esperado o exercício de um poder punitivo, violento, em face de ofensas ou transgressões às instruções emitidas através de bandos. Neste tipo duplo de actividade judicial, aliás, residia uma das principais funções do bando colonial como colectivo de justiça.

As palavras do governador na boca dos seus oficiais podiam, assim, em primeiro lugar, produzir a tranquilidade e a harmonia entre pessoas ou grupos desavindos. As sentenças do governador, transmitidas através dos bandos, podiam bastar para pôr fim a situações de discórdia e luta política - ou até, já, de guerra - envolvendo as autoridades nativas e os membros das classes aristocráticas. "A necessidade da própria conservação", escreveu em 1881 o governador Cardoso de Carvalho, "obriga os diversos reinos a aceitarem o nosso governo como medianeiro e juiz nas suas contendas, não havendo da parte de nenhum reino sequer a ideia de absorção doutro" (Carvalho para Governador de Macau e Timor, 11 Maio 1881) A arbitragem de disputas ocorria frequentemente a pedido de (pelo menos) um dos representantes das partes timorenses envolvidas, na expectativa de que a interferência do governador beneficiasse a sua causa ou, simplesmente, pusesse fim ao conflito.

Em 1875, a intervenção do governador Hugo de Lacerda, através de um bando, foi requerida por timorenses para arbitrar um conflito de longa data entre o coronel regente de Bibiçusso, D. Matheus Soares, e um principal (nobre, parente da linhagem real), D. Florêncio Hornay, então em estado de guerra (Lacerda para Governador de Macau e Timor, Jan. 1875). Por intermédio de bandos de paz, o governador actuava como força unificadora num território fragmentado numa pluralidade de reinos, onde linhagens reais e aristocráticas se digladiavam pelo poder. Todavia, a arbitragem do governador podia ser insuficiente e ineficaz, caso não recebesse pleno reconhecimento ou fosse rejeitada por uma das partes envolvidas. Nesse caso, os bandos de paz podiam agir como antecipadores da outra face justiceira do governador: 
os bandos de guerra. A poderosa dialéctica entre guerra e paz manifestada pelos bandos foi assim resumida pelo governador Afonso de Castro, no seu influente livro As possessões portuguezas da Oceânia, de 1867:

Guerras de povoação contra povoação, de reino contra reino, houve de certo; mas terminariam sempre com a publicação de bandos, como tantas vezes acontece em Timor, onde tão frequentes são estas guerras, que chegam a ser vistas com certa indiferença pelo governo, que só toma medidas para lhes pôr termo, quando alguma das partes contendoras apela para o governador, e ainda assim este só intervém com a força, quando se desobedece ao bando de paz (Castro 1867:123).

Os chamados "acontecimentos de Aiassa", que conduziram à guerra do governo contra os povos Lamaquitos em 1891-92, são exemplo desta dinâmica dialéctica. Em 1891, o governador Cipriano Forjaz foi chamado pelo régulo de Lamaquitos para mediar e conciliar um conflito entre este régulo e outros importantes grupos locais. Forjaz aceitou o pedido, enviando um bando composto por um alferes e um cabo de $1^{\mathrm{a}}$ linha do exército português, o chefe do Serviço de Saúde, e uma pequena força de moradores (tropas irregulares nativas) com caixa e bandeira, para proclamarem as instruções conciliadoras do governador junto à povoação de Aiassa. Contudo, no acto de expedir o bando no local, a povoação negou-se a receber a justiça do governador. Um militar foi alvejado e gravemente ferido por tiroteio vindo da povoação; alguns moradores caíram mortos ou feridos na escaramuça que se seguiu. Em consequência deste acto de "desobediência", o governador declarou guerra a Aiassa, a qual durou mais de um ano e ocasionou pesadas perdas (Forjaz para Governador de Macau e Timor, 23 Nov. 1891). José Gomes da Silva, médico e chefe do Serviço de Saúde, testemunhou a ocasião e, num extenso relatório sobre a campanha, relatou o momento de ataque ao bando apaziguador, que precedeu a guerra:

No dia 5 [de Setembro de 1891], reunido o bando sobre uma colina que domina a povoação de Ayassa, o cabo Clementino [que falava a língua local, o kemak], depois de alguns rufos de tambor para chamar a atenção, declamou em voz alta, ao modo do país, as instruções do bando. Que o governo mandava ali a bandeira para à sombra dela se fazer a devida justiça; que viessem os principais [nobres, parentes da linhagem real] de Ayassa e dissessem as suas razões de rebeldia; que o governo desejava a paz e a isso vinha; que não receassem aproximar-se porque a força armada que ali estava era apenas a guarda da bandeira etc. 
Não houve resposta. A gente que estava na povoação fez semblante de nada ouvir. E julgando realmente que eles não teriam ouvido bem, o comandante deu ordem de avançar ao passo, até aos postos que precedem a povoação. Aí repetiu-se o bando.

Desta vez não houve resposta. O cabo Clementino caiu ferido por uma bala, que penetrou na região púbica. O comandante mandou então carregar, avançando sobre a povoação [...] (Silva 1892:13).

Este relato deixa claro que os bandos não se esgotavam em enunciações linguísticas. Longe de serem só palavras ditas, bandos coloniais constituíam um colectivo, materializado numa rede de palavras, sons, coisas e pessoas a bandeira, o rufo do tambor, o cabo, a guarda dos soldados, as instruções declamadas... Como tal, funcionavam com vistas à instauração da paz e à resolução de conflitos. Mas serviam igualmente à propulsão de guerra. Para quem reconhecia os parâmetros legitimadores da punição inscritos na rejeição a bandos, a guerra colonial accionada pelo governador podia, portanto, constituir uma acção válida de retaliação a um gesto de violação a bandos - violação não apenas no sentido de um gesto abstracto de dissensão a instruções normativas, mas, como ilustra a ocorrência em Aiassa, no sentido físico de agressão às corporalidades do colectivo de justiça. No caso de recusa da clemência do governador, de ataque aos seus emissários, ou em geral de transgressão ou violação às disposições dos bandos, o governador tinha legitimidade para exibir o outro lado do seu poder justiceiro: a punição e o terror.

Violentas campanhas punitivas - envolvendo mortes e decapitações, incêndios de aldeias inteiras e saques devastadores - podiam ser organizadas como resposta a tais agressões e infracções. Por norma, com efeito, o governo apenas tomava medidas punitivas na sequência de actos considerados transgressores aos "contratos" que ligavam timorenses e portugueses. Estas (re)acções punitivas ocorriam, em termos típicos, em consequência de desobediências aos bandos, agressões físicas aos oficiais executivos, quebras no cumprimento das obrigações nativas do sistema tributário (por exemplo, o não pagamento do imposto de finta, tributo em géneros pago ao governo pelos reinos; ou a recusa em dispensar arraiais, guerreiros nativos, para a guerra), ou outros comportamentos ofensivos que pudessem desrespeitar as regras de etiqueta que deviam regular as relações timorenses com as autoridades portuguesas. A violência, porém, não era um produto automático das alegadas faltas ou desobediências; era vista como derradeiro recurso punitivo. As primeiras palavras ditas pelo governador aos transgressores, também por via de bandos, traziam 
uma dádiva de perdão, oferecida mediante uma compensação material: as multas.

Por meio de bandos, o perdão pelas faltas cometidas na sequência de rupturas com as determinações do governo era prometido em troca do pagamento de multas, as quais serviam como compensação pelas perdas causadas e pelos gestos de ofensa e desobediência. Estas multas eram estabelecidas de forma discricionária pelo governador ou, mesmo, no local, pelos seus delegados, sendo geralmente pagas em géneros. Ainda que o seu valor pudesse ser medido em moedas correntes em Timor (como o pardau ou o florim), os objectos transaccionados nas multas incluíam bens de significativo valor tradicional nas culturas de Timor: por exemplo, búfalos, produtos agrícolas, tecidos (tais ou sarões timorenses), cavalos, discos de ouro e prata, ou mutiçala (colares de contas de coral). Muitas vezes, o pagamento de multas podia impedir o derramamento de sangue. Contudo, se os transgressores se recusassem a aceitar a troca proposta (e, nomeadamente, os valores envolvidos), a punição do governo tomava o curso da violência. Nestes casos, a declaração de guerra apenas adquiria localmente foros de legitimidade, na circunstância de ser recusada ou desrespeitada a troca de clemência por multas.

Os bandos de guerra tinham lugar, então, no início das confrontações. Durante o período das chamadas guerras de "pacificação", nas décadas de 1890 e 1900, os ataques às aldeias eram usualmente precedidos pela proclamação de um bando pelos oficiais militares portugueses, no qual se prometiam perdão e justiça suave em troca de arrependimento e multa. Caso contrário, declarava-se guerra. Quando falhavam estes cerimoniais e a troca apresentada era rejeitada, os ataques ocorriam sob a cobertura de punição legítima. A guerra colonial prefigurava, assim, uma das dimensões dualistas da autoridade jural, apresentando-se como um restabelecimento legítimo da ordem nos assuntos seculares. Neste quadro, a guerra tomava forma como um dos efeitos performativos da voz do governador - um evento do terror da lusofonia cerimonial dos portugueses.

Mas os bandos existiam em Timor Leste não apenas na forma de uma instituição de usos coloniais, mas também como colectivo de justiça nos usos timorenses. Ao longo do tempo, o bando passou para os usos tradicionais da justiça timorense, persistindo nos vocabulários nativos através da expressão bandu. Porventura mediante um processo criativo de imitação, os bandos do governador português transitaram para as práticas timorenses de administração e regulação judicial, nesse processo de passagem sofrendo, contudo, algumas mudanças. Vejamos então, brevemente, no que possam ter consistido bandos ou bandus timorenses no período colonial. 


\section{Bandus timorenses}

Como vimos, os reis timorenses recebiam poderes político-jurais do governador, deste modo participando do círculo de delegação centrado em Díli, a título geral de "vassalos" do rei de Portugal. A autoridade jural timorense, eleita segundo procedimentos tradicionais, tendia assim a coincidir com o coronel, rei ou régulo investido pela administração colonial. ${ }^{15}$ Mas este círculo de "vassalos" estava longe de configurar um grupo submisso e reverente; ao invés, como o demonstram as muito frequentes guerras entre Díli e os reinos timorenses, imperava entre os reinos, e entre os reinos e Díli, um estado de hostilidade e agitação política, uma situação de "independência" e "rebeldia" que provocava grande ansiedade nos governadores. A delegação colonial do poder aos liurais timorenses instigava a criação em seu entorno de uma pluralidade de autoridades políticas que, a qualquer momento, por força dos sinais de autoridade de que se achavam investidas, podiam actuar de forma autónoma, à revelia do governo - ignorando, recusando, ou mesmo disputando directamente a posição do governador colonial. Os reinos e os seus reis configuravam, assim, uma rebelde topografia política, centrada em Díli e nas suas irradiações cerimoniais, mas articulando focos de autoridade autónomos ou até alternativos. ${ }^{16}$

Esta paisagem política plural e efervescente, alimentada ao longo do tempo pelos mecanismos cerimoniais do governo português, fornece pistas importantes para entender o aparecimento dos bandos enquanto instituição nativa. A circulação do composto bandos para os usos jurídicos timorenses percebe-se, a meu ver, no quadro dessa dinâmica de delegação e (in)dependência, que fazia de liurais/reis a um tempo consumidores, imitadores e corruptores por excelência dos signos, dos objectos e das forças da autoridade emanada de Díli. Os bandos dos liurais podiam ser, ou não, feitos em nome do governador - e até é de crer que, por regra, o não fossem. Nas suas modalidades timorenses, os bandos adquiriram identidade e expressão relativamente autónomas do governo português, ainda que se mantendo subsidiários do princípio performativo da ordem jural, inerente aos bandos coloniais. Na vida própria que ganharam dentro dos reinos, bandos não seriam mais a voz do governador. Tornar-se-iam a voz singular do senhor que reclamava autoridade maior na imposição de lei e de justiça, o coronel, o rei, o liurai. Bandos nos usos timorenses preservaram assim o carácter de acto sentencioso, com força de lei e de proibição, emitido pela superior autoridade timorense no domínio jural. Porém, nessa passagem, as matérias que os formavam modificar-se-iam substantivamente. 
A expressão tétum bandu, derivada da palavra portuguesa bando, aponta para os sentidos da apropriação timorense. O antropobiólogo António de Almeida, que conheceu Timor Leste nas décadas de 1950 e 1960, referiu-se ao termo bandu como "generalizado", "significativo de proibição legal ou de prática consuetudinária"; nalgumas zonas (caso da ponta leste da província), a expressão seria mesmo usada em substituição do importante termo tétum lulik (sagrado, proibido) (Almeida 1976-77:124). O termo bandu é preservado até hoje no léxico tétum timorense com o significado, segundo Luís Costa, de "proibição", integrando o sentido de "ordem dada por meio de pregão ou bando", dere bandu servindo para denotar o acto de "apregoar o bando (tocando tambor)" (Costa 2001:49). ${ }^{17}$ Esta definição evoca em pleno o sentido português. Mas tratar-se-ia bandu de um termo linguístico que não mais fazia do que replicar sentidos portugueses, renomeando bandos do governador? Ou, antes, tratar-se-ia mesmo de uma expressão alusiva a uma modalidade institucional distinta, uma versão inovadora desses bandos solenes de caixa e bandeira que chegavam de Díli? Se assim for, no que consistiam, nas suas manifestações indígenas, bandus timorenses?

A evidência documental de que dispomos sobre as formas timorenses bandus é escassa. Possuímos ainda assim elementos suficientes para presumir não só uma considerável difusão no interior dos reinos timorenses desde pelo menos o século XVIII, como também para inferir que os bandus constituíram, em certa medida, versões timorenses dos colectivos de justiça introduzidos pelos portugueses - porém consideravelmente autónomas e singularmente distintas em relação aos seus congéneres coloniais. Reclamando para si uma autoridade análoga à do governador e seus executivos no domínio jural, os reis de Timor podiam expressar por bandus, através de agenciamentos próprios, as suas determinações judiciais. À imagem daqueles que chegavam de Díli, bandus podiam ser também sentenças e ordenações emitidas pelos régulos e transmitidas aos povos através de actores executivos. Mesmo aqueles régulos hostis aos portugueses podiam usá-los para exercer a sua autoridade.

Em 1895, por exemplo, na véspera do confronto com forças portuguesas invasoras, o rei de Manufahi teria proclamado um bando, proibindo todos os seus súbditos de chegarem a acordo com o governo português; ou, nas palavras do governador que registou o facto: "[o régulo de Manufahi] declarou por meio de um bando que não consentia que ninguém do reino se entendesse com o governo" (Silva para Governador de Macau e Timor, Jan. 1895). É possível, ainda, que o recurso a bandos pelos reis timorenses remontasse a épocas antigas de contacto com a presença portuguesa. No cé- 
lebre Documento Sarzedas — conjunto de informações e instruções dirigidas pelo conde de Sarzedas, governador do Estado da Índia, ao governador de Timor, Cunha Gusmão, em 1811 — é feita referência à imposição de multas a escravos pelos reis timorenses, o motivo sendo a transgressão de bandos emitidos por estes últimos: "por bandos que eles [escravos] transgrediram" (Sarzedas apud Castro 1867:202).

A ritualização associada a esses bandos dos reis poderia, em ocasiões várias, replicar simplesmente aquela cerimonialidade marcial — soldados, tambor e bandeira - que os governadores emprestavam à emissão de bandos portugueses. Sobre isto, contudo, não temos de momento documentação histórica precisa. O certo é que a importância dos bandos para a autoridade tradicional timorense é atestada pelo facto de os seus princípios activos de comunicação e instauração da ordem terem sido mimeticamente apropriados, ao longo do tempo, pelas culturas políticas e judiciais nativas. Certo é também que o colectivo que expressava e produzia esses princípios podia ser substancialmente diferente. Tal como os bandos coloniais, os bandos nativos emergiam como uma emanação da principal autoridade jural do reino, mas pareciam ser outros a matéria e o modo de comunicação ritual.

Bandos portugueses do governador e bandus timorenses dos liurais canalizavam funções e forças justiceiras análogas através de colectivos distintos. Uma das mais importantes diferenças passava pela materialidade e pela sonoridade (ou ausência dela) do regime de signos utilizado. De facto, o que desde logo ressalta nas expressões indígenas dos bandus, tal como apresentadas nos testemunhos portugueses da época, é a dominância de objetos materiais e elementos não verbais. Num texto de 1885, o major José dos Santos Vaquinhas - militar activo vários anos na colónia e observador perspicaz dos costumes locais - deixou-nos uma rara e valiosa descrição dos bandos timorenses.

As ordens expedidas pelos régulos ou pelos chefes para conhecimento do povo em geral são por meio de bandos, e quando essas ordens têm somente efeito num local determinado, e para que não se alegue ignorância na localidade onde elas são dadas, procede-se pela seguinte forma:

Próximo aos caminhos são dependurados num poste, ou amarrados a um pé de coqueiro ou de qualquer árvore, certos e determinados objectos, que por si indicam a espécie da ordem; por exemplo, uma folha de coqueiro, um pé de carneiro, uma espada de pau, uma corda e um ovo, e outros utensílios combinados, servem para indicar o objecto da ordem, de qualquer proibição, e até mesmo a importância da multa que os transgressores têm a pagar. 
A combinação destes sinais varia entre os reinos, e contudo todos os indígenas compreendem mais ou menos estes perfeitos logogrifos, que são curiosos, como curiosa é a significação de alguns deles (Vaquinhas 1885:63-64).

Emitidos por autoridades timorenses, bandos constituíam um sistema de signos-objectos, uma linguagem arranjada por objectos legíveis na paisagem para os possuidores dos códigos de leitura dos sinais do poder jural. Ainda um colectivo de justiça, mas um colectivo reconfigurado pela substituição das matérias e a anulação da verbalização linguística. Dispensava-se a sonorização da voz, a circulação de palavras, mas não a existência de uma linguagem do poder, doravante visual. Esta fazia-se ver e ler num colectivo de coisas, numa liturgia codificada de objectos, que tomavam o lugar da liturgia marcial dos bandos coloniais. Importa ter presente, contudo, que o exercício da palavra, nomeadamente em contextos cerimoniais, possuía (como ainda possui) nas culturas timorenses, importante valor em contextos de intervenção jural. ${ }^{18}$ É assim possível — embora tal não se encontre documentado - que os actos de instauração e instalação física de bandus na paisagem fossem precedidos de outras práticas jurais que envolvessem o exercício verbal da palavra pelos liurais ou por seus porta-vozes, oradores rituais, ou estivessem de algum modo ligados a elas. É em todo caso significativo que, rotinizados na paisagem, os bandus constituíssem uma presença constante da voz jural do liurai exclusivamente manifesta através de arranjos de coisas materiais.

Nos séculos XIX e XX, esses bandus tornaram-se provavelmente uma importante modalidade da justiça costumeira timorense, utilizada não só por liurais, mas também, talvez, por autoridades timorenses menores que reclamassem para si autoridade jural equivalente à do liurai e/ou autónoma. Em 1943, outro experiente militar colonial, o capitão José Simões Martinho, baseando-se em quase 25 anos de serviço em Timor, voltou a descrever assim o costume de os liurais, na primeira metade do século XX, exercerem a lei através de bandos:

Os usos e costumes constituíam a lei que todos deviam respeitar, menos o Léo-Ray. Este, como senhor que era da vida e dos haveres dos súbditos, podia alterá-la, suspendê-la e até revogá-la. Sentenças, ordens, avisos e instruções de execução imediata ou permanente eram transmitidos em bandos, que se afixavam à beira dos caminhos. [*]

[*] Consistia o bando, que deixou de ter acatamento fácil por se haver tornado função de qualquer chefe insignificante e até dono de algumas mangueiras, em duas estacas de dois metros de altura aproximadamente, suportando, 
horizontalmente colocada, uma vara donde pendia o aviso ou edital. Este era de fácil leitura: Um coco ainda tenro, por exemplo; uma pequena corda; uma palmatória; um pé de cabrito e umas cascas de ovos indicavam que era proibido colher cocos, sob pena de prisão (corda), de apanhar algumas palmatoadas (palmatória) e de pagar uma multa (cabrito e ovos). O número de ovos de multa era por vezes indicado por um cordel com nós, correspondendo um a cada ovo (Martinho 1943:221).

Sem palavras, bandus na paisagem diziam lei, produziam efeitos de ordem e justiça. Eis-nos perante uma descrição contrastante com as imagens dos bandos coloniais - muito embora não com as suas orientações estratégicas primeiras. Importa notar, em suma, os principais pontos de proximidade e distância entre bandos coloniais e bandus nas suas expressões timorenses. Tal como os bandos coloniais, os bandos timorenses preservavam a sua funcionalidade performativa, cerimonial, na forma de um colectivo justiceiro. Assumiam-se como o dispositivo, por excelência, de comunicação e instauração do discurso poderoso na ordem da justiça. Assim, bandus eram a voz da autoridade jural, sentenças e instruções que articulavam proibição e contravenção ou castigo: o estabelecimento de um proibido; a comunicação de um acto punitivo — uma multa, uma sentença — em contrapartida a uma transgressão.

Esta semelhança nos princípios performativos do discurso não correspondia às suas expressões materiais, pois os bandus constituíam uma instituição discursiva feita de coisas, uma liturgia de objectos. Não exprimiam a voz de autoridade jural na forma de palavras, ou tão pouco no som português de uma lusofonia; não incluíam sequer tambores, soldados e mediações sonoras. Representavam um colectivo não linguístico no qual coisas silentes se substituíam a pessoas e a sons como signos e agentes da acção executiva da autoridade.

\section{Conclusão}

o discurso verdadeiro - no sentido forte e valorizado da palavra - o discurso verdadeiro pelo qual se tinha respeito e terror, aquele ao qual melhor seria submeter-se, porque reinava, era o discurso pronunciado por quem de direito e segundo o ritual requerido; era o discurso que dizia a justiça e atribua a cada um o seu papel; era o discurso que, profetizando o futuro, não anunciava somente o que iria passar-se, mas contribuía para a sua realização, consigo levando a adesão dos homens e, assim, congeminando o destino (Foucault 1971:17). 
Este artigo explorou o significado dos usos da palavra portuguesa no quadro das práticas de governo colonial em Timor Leste, entre a segunda metade do século XIX e as primeiras décadas do século XX. A instituição do bando, através do qual os governadores e os seus oficiais executivos emitiam instruções, produziam deliberações judiciais e procuravam exercer comando sobre as populações nativas, mostrou que não é possível investigar os regimes de poder do discurso colonial armados das idealizações pressupostas em conceitos estritamente literários e linguísticos de discurso. Privilegiando as relações entre palavra, rito e materialidade nos bandos portugueses em Timor, este texto partiu da hipótese de que o discurso do poder colonial, bem como o poder desse mesmo discurso devem entender-se como evento performativo no interior de relações sociomateriais específicas, e não para além delas.

Noções abstractas de "discurso" e de "linguagem" revelam-se assim epistemologicamente improdutivas na pesquisa dos usos práticos da palavra colonial, pois, como nos revelam os bandos de Timor, as palavras do governo colonial não se manifestavam na forma incórporea de "língua" ou mesmo na mera forma desencarnada de "palavra". Configuravam, em situação, o que designei por colectivos de justiça: dispositivos heterogéneos, estilizados nas matérias e na gestualidade litúrgicas de ritos, nos quais coisas, pessoas e palavras imbuídas de especial autoridade se organizavam com vistas a gerar efeitos de poder, manejando a (des)obediência das populações timorenses. Sem tambor, sem bandeira, sem as pessoas, os códigos e as etiquetas que acompanhavam a declamação de palavras, a lei do governador de pouco ou nada valeria. Por conseguinte, reduzir, neste contexto, a análise do "discurso colonial" às suas formas linguísticas, escritas e/ou textuais, corresponde a amputar as relações de poder em que esse mesmo discurso se inscrevia e para as quais a sua performance contribuía.

Tais limitações são tanto mais evidentes quanto uma das condições socio-históricas talvez mais importantes para perceber o significado da palavra colonial no império português consista na associação estabelecida com actos de autoridade e governo, e bem assim com as materialidades e as formas rituais em que esses actos adquiriam importância. Se abordada, então, como sonoridade que os seus locutores associavam às matérias do poder e às roupagens da autoridade, a lusofonia colonial - em Timor, mas talvez também noutros contextos de colonização portuguesa — não pode ser reduzida à ficção de simples som da "língua portuguesa", à mera condição de uma literal luso-fonia.

Neste sentido, este ensaio constitui também apelo à necessidade de evitar definições redutoramente linguísticas e literárias da lusofonia no 
estudo histórico antropológico do discurso português em situação colonial. Crucial, então, para interpretar o discurso do poder e o poder do discurso na história imperial é o facto de, em várias ocasiões — das quais o fenómeno dos bandos é ilustrativo - o discurso colonial aspirar a essa derradeira condição de autoridade a que nos alude Michel Foucault em epígrafe, ao referir-se ao discurso da Antiguidade Clássica. Isto é: a aspiração à condição de discurso realizador que, na medida em que é proferido por oficiais legítimos em cenários e liturgias apropriados, adquire força de lei, de verdade e de justiça, garantindo a obediência dos seus ouvintes.

Este ensaio demonstrou como os bandos coloniais em Timor Leste exemplificam esta mesma aspiração dos portugueses à posição de locutores de um discurso que reinava, "pelo qual se tinha respeito e terror". Como vimos, porém, esta submissão nem acontecia sempre, nem era tão durável e imediata como se desejava. A eficácia simbólica e performativa dos bandos não era total, nem constante. Os timorenses podiam rejeitar os bandos e contrariar a sua força; podiam usá-los para os seus propósitos e interesses; e chegavam mesmo a servir-se da autoridade jural de que se achavam investidos para reinstaurar, nas comunidades, bandus enquanto formas indígenas de actuação e comunicação do poder. Neste sentido, a inscrição genética da palavra portuguesa em regimes cerimoniais de autoridade e de governo é importante não apenas para o nosso entendimento da linguagem da autoridade colonial. É também fundamental para perceber os usos e as apropriações (incluindo as subversões) do discurso colonial pelas populações nativas.

A este título, este ensaio revelou que a palavra "em-si-mesma" não foi o elemento privilegiado nas circulações a que a linguagem cerimonial do poder colonial se viu sujeita nos usos das culturas nativas. Como vimos, em Timor Leste os bandos adquiriram uma vida autónoma como mecanismo do discurso verdadeiro e justiceiro dos liurais nos reinos. Menos do que servir à transmissão do comando de Díli, os bandos ganharam uma biografia alternativa enquanto formas de exercício directo do poder dos reis, centros de emanação da voz da justiça à revelia da voz do governador. Nas suas apropriações nativas, os bandus timorenses davam continuidade aos princípios presentes no bando colonial. Mantinham uma aura de inviolabilidade e proibição, exprimindo a ideia de um acto de lei obrigatório, cuja transgressão envolvia consequência punitiva. Na administração feita nos reinos pelos liurais de Timor Leste, o termo adquiriu novas e suplementares significações indígenas. Estas, por um lado, assimilavam a força e a centralidade que os bandos ocupavam na administração colonial da justiça; mas, por outro lado, transformavam de forma criativa a sua linguagem litúrgica. No lugar de palavras, de oficiais do exército, de soldados e tambores, o colectivo dos bandus 
apresentava "espadas de pau", "pés de carneiro", "folhas de coqueiros"... Por meio dessa recomposição de matérias, era a voz justiceira do liurai que adquiria modo de existir como discurso que reinava, que dizia a justiça, que inspirava respeito e terror.

Assim, nos reinos timorenses, bandus vieram a distinguir-se como um colectivo de justiça de carácter eminentemente não linguístico, no qual a agência de coisas insonoras se substituía à acção executiva de pessoas (oficiais e soldados), palavras e instrumentos portugueses. Muito provavelmente, pois, os bandus dos liurais não se fizeram simplesmente de matérias e lógicas apropriadas aos bandos do governo; a sua constituição teria mobilizado também outras tradições e recursos jurais, difíceis de destrinçar na documentação de arquivo, mas cujas natureza e origens seriam em grande medida autónomas, ou até anteriores à presença portuguesa.

Conforme sugeri, tudo indica que foi esta a forma singular que bandos ou bandus tomaram nos reinos timorenses durante os séculos XIX e XX, inclusive após a prática ter caído em progressivo desuso administrativo pelos governadores portugueses, talvez, sobretudo, após a Segunda Guerra Mundial. Esta hipótese, contudo, carece de verificação histórica, sendo difícil proceder à datação exata deste hipotético desuso. É possível mesmo que, até mais tardiamente, o bando tenha mantido conotação com o poder colonial e a própria instituição preservado funções justiceiras efetivas na administração jural portuguesa. Em 1994, por exemplo, Xanana Gusmão, líder histórico da Resistência e carismático político timorense, escreveu sobre a violência punitiva da administração portuguesa, recordando: "presenciei ordenanças e moradores saindo ou regressando com o 'bando' trazendo infractores ensanguentados" (Gusmão 1994:3). Paralelamente, evidência de bandos nos usos timorenses de justiça pode ser encontrada em registos de observadores portugueses até pelo menos a década de $1960 .{ }^{19}$ É provável, ainda, que a sua persistência se possa reconhecer na contemporaneidade, no contexto dos recrudescimentos dos mecanismos da justiça costumeira em Timor Leste (cf. Hohe \& Nixon 2003; Babo-Soares 2004; McWilliam 2007; Simião 2011). Na actual instituição jural designada, em tétum, por tara bandu - ritos e cerimónias dirigidos à imposição de proibidos e em geral à regulamentação dos usos da paisagem, do ambiente e dos recursos naturais - ressoam, reinventados, ingredientes dos bandos dos portugueses e dos bandus dos liurais timorenses, tal como estes foram sendo descritos ao longo do período colonial (cf. Yoder 2007; Soares 2004). ${ }^{20}$ A voz dos bandos não parou de soar no território. Transformados, os antigos colectivos da justiça feita por governadores e liurais continuaram - e talvez ainda continuem - a ter novas vidas na justiça tradicional de Timor Leste. 
Recebido em $01^{\circ}$ de janeiro de 2012

Aprovado em 04 de dezembro de 2012

Ricardo Roque é investigador auxiliar no Instituto de Ciências Sociais, Universidade de Lisboa, e Postdoctoral Research Fellow no Departamento de História \& Centre for Values, Ethics and the Law in Medicine, Universidade de Sidney. E-mail: <ricardo.roque@ics.ul.pt>

\section{Notas}

'Este ensaio é um resultado dos projetos Mimetismo Colonial na Ásia e África Lusófonas e O Governo dos Outros. Imaginários Políticos no Império Português (1496-1961) ambos financiados pela Fundação para a Ciência e Tecnologia, Portugal (respectivamente, referências PTDC/CS-ANT/101064/2008 e PTDC/HIS-HIS/104640/2008). O autor é titular de uma Postdoctoral Fellowship do Australian Research Council (referência FL 110100243). Versões iniciais deste artigo foram apresentadas em seminários em Macau, Lisboa e Díli no decurso de 2011 e 2012. Agradeço a Ângela Barreto Xavier, às audiências dos seminários e a um parecerista anónimo os comentários e as sugestões. Ao longo do texto, traduzi para o português as citações originalmente em francês e inglês. Na edição para publicação em Mana foi mantida a ortografia vigente em Portugal após o acordo estabelecido para a Nova Ortografia em países de língua portuguesa.

${ }^{1}$ A presença portuguesa na ilha de Timor, através da actividade de missionários, remonta ao século XVI. Em 1769, os portugueses foram forçados a abandonar a sede de governo em Lifau, no lado ocidental, reinstalando-se em Díli, de onde estenderam a sua administração à parte leste da ilha até a invasão indonésia em 1975.

${ }^{2} \mathrm{O}$ nexo discurso-poder tem sido objecto de extensa literatura em história e antropologia do colonialismo. As referências obrigatórias incluem Said (1978) e Cohn (1996). Sobre este debate tomo posição em Roque e Wagner (2012).

${ }^{3}$ A dimensão ritual dos impérios coloniais europeus é, em geral, um tópico estabelecido na recente história imperial, muito por força da obra colectiva editada por Hobsbawm e Ranger (1983). Porém, a conexão entre rito e discurso não tem sido privilegiada nas análises. Noutro trabalho explorei em maior profundidade a importância da ordem cerimonial para o governo colonial português em Timor Leste (Roque 2010).

${ }^{4}$ Compare-se também com o influente trabalho de Bernard S. Cohn sobre o estudo e a aprendizagem de línguas nativas como instrumento e estratégia do poder colonial inglês (Cohn 1985; cf. Dodson 2005). 
${ }^{5}$ Conforme afirmou Foucault em um dos seus escritos, o acaso (hazard), a descontinuidade e a materialidade devem ser tidos como elementos cruciais na análise dos discursos (Foucault 1971:61).

${ }^{6}$ Este apelo sociológico de Bourdieu é aqui inspirador, mas não adoto a sua linha teórica sobre o discurso, nomeadamente as teorias de habitus e campo. Para uma revisão crítica mais ampla da relação entre Bourdieu e a antropologia linguística, veja-se Hanks (2005); mas sensibilidades sociológicas várias sobre os usos sociais do discurso têm marcado terreno, por exemplo, na antropologia da linguagem legal (para uma revisão, veja-se Mertz [1994]).

${ }^{7}$ A expressão Tétum liurai servia para designar, em Timor, os "senhores da terra", as autoridades timorenses que tradicionalmente se investiam dos poderes sobre o domínio da justiça, da lei e da guerra.

${ }^{8}$ Ver, sobre estas conexões, Roque (2010: parte I).

${ }^{9} \mathrm{O}$ corpo como metáfora do poder e do governo é também um tópico comum nas culturas políticas do Sudeste asiático (cf. Schulte-Nordholt 1971: caps. XI e XII).

${ }^{10}$ Alguns dos materiais explorados nesta e na seguinte secção sobre bandos coloniais foram também objecto de análise noutro trabalho, em linhas complementares às deste artigo (Roque 2010: cap. 2).

${ }^{11}$ Veja-se também as entradas para édito em Bluteau (1712-1728, tomo III:13) e Silva (1813:647).

${ }^{12}$ A etimologia indo-asiática da palavra, radicada no sânscrito, aponta, porém, para uma significação distinta. Socorrendo-se de uma indicação no dicionário de Morais Silva, Dalgado fez radicar o significado asiático de bando - equivalente a "valado da várzea" - no concani bandh e no sânscrito bandha. Segundo o autor, em Goa, o termo bando, na sua acepção asiática, não era "actualmente usado no português local" (Dalgado 1919, vol. I:93). Porém, é de crer que, na acepção "europeia" de acto e palavra de lei, o termo bandos tenha se mantido em uso na administração de Goa até pelo menos meados do século XIX (veja-se Xavier 1840-51).

${ }^{13}$ Não é de excluir, ainda, a hipótese de formas rituais de exercício da palavra da lei persistirem nos usos do Portugal metropolitano de Oitocentos, não sendo, portanto, uma singularidade exótica dessas colónias asiáticas. O estudo do recurso a bandos e/ou a éditos no Portugal do século XIX carece, porém, de investigação.

${ }^{14}$ Importa notar que a palavra escrita era preferida nos circuitos mais estritamente "europeus" da administração. Aqui, dominava a circulação de tipo burocrático, de normas e comandos escritos, na forma de epístolas e ofícios. A palavra oral, cerimonial, a voz do governador através de bandos, dominava na relação administrativa com os reinos e as populações timorenses. Todavia, isto não excluía que, desde o século XVIII pelo menos, a palavra escrita fosse utilizada nas 
comunicações directas entre portugueses e certos liurais de Timor Leste. Muitos reis e aristocratas timorenses falavam português e, como documentou José dos Santos Vaquinhas nas décadas de 1870-80, alguns reinos mantinham arquivos em que a circulação de cartas entre governadores e liurais estava bem documentada (Vaquinhas 1884, 1885).

${ }^{15}$ Refira-se que os processos de eleição de reis e liurais não seguiam apenas procedimentos e instituições portuguesas e coloniais; incluíam também outros complexos processos de selecção e eleição de chefias, que se mantinham autónomos e próprios das sociedades timorenses. Este duplo procedimento coexistiu durante o período colonial aqui analisado, concorrendo para estabelecer a autoridade jural dos reis e das suas linhagens. Sobre o complexo processo de eleição nas comunidades timorenses, veja-se, por exemplo, Castro (1863:29) e França (1897:232).

${ }^{16}$ Este tipo de paisagens políticas tem sido apontado como distintivo das culturas políticas "tradicionais" do Sudeste asiático (por exemplo, Tambiah [1977]; Colombijn [2003]). Embora a literatura tenda a excluir por inteiro a influência europeia da formação dessas paisagens, o caso de Timor Leste aponta no sentido inverso (Roque 2010, 2011b).

${ }^{17}$ A expressão não consta porém num dos primeiros dicionários Tétum-Português, produzido pelo militar Rafael das Dores, em 1907.

${ }^{18}$ Descrições coloniais portuguesas desse período, por exemplo, destacam a importância do homulac, orador cerimonial timorense em situações de conflito e guerra (cf. Roque 2012).

${ }^{19}$ Em 1976, António de Almeida deixou registo semelhante sobre a linguagem dos bandus, acentuando o seu valor como comunicado de punições a actos transgressivos, e a qualidade neles assumida pelos objectos como testemunhos da palavra do senhor jural e "normas costumeiras" (Almeida 1976-77:535-536).

${ }^{20}$ Tara significa colocar ou pendurar objectos como sinal de bandu (proibir), sendo que tara bandu tem o sentido de lei ou código de representação simbólica associado à instituição de regras para a preservação de ambientes naturais. Agradeço a Vicente Paulino esta observação. 


\section{Referências bibliográficas}

ALMEIDA, António de. 1976-1977. “Contribuição para o estudo dos nomes 'lúlik' (sagrados) no Timor de expressão portuguesa". Memórias da Academia das Ciências de Lisboa (Classe de Ciências), XXI:121-42.

ANÓNIMO. 1879. "Leal Senado da Câmara. Bando. 28 Novembro 1879". Boletim da Província de Macau e Timor, XXV(48):289.

AUSTIN, J. L. 1962. How to do things with words. The William James lectures delivered at Harvard University in 1955. Cambridge: Harvard University Press.

BABO-SOARES, Dionisio. 2004. "Nahe Biti: the philosophy and process of grassroots reconciliation (and justice) in East Timor". The Asia Pacific Journal of Anthropology, 5(1):15-34.

BHABHA, Homi. 1994. The location of culture. Londres: Routledge.

BLUTEAU, Raphael. 1712-1728. Vocabulario portuguez e latino. 10 vols. Coimbra: Collegio das Artes da Companhia de Jesus.

BOURDIEU, Pierre. 1982. Ce que parler veut dire. L'économie des échanges linguistiques. Paris: Fayard.

CALLON, Michel \& LAW, John. 1995. "Agency and the hybrid collectif". South Atlantic Quarterly, 94(2): 481-507.

CARVALHO, Augusto Cardoso de, para o Governador de Macau e Timor. 11 Maio 1881. Lisboa: Arquivo Histórico Ultramarino, Macau e Timor, ACL SEMU_DGU_1R_002_Cx 2, 1881.

- Portaria no 25. 1 Março 1881. Macau: Arquivo Histórico de Macau, AC/17/686/A.G12. P-274.

CASTRO, Afonso de, para MNSNU (Ministro e Secretário de Estado dos Negócios da Marinha e Ultramar). 4
Abril 1863. Lisboa: Arquivo Histórico Ultramarino, Macau e Timor, AHU ACL_SEMU_DGU_005_Cx29_1863. - 1863. "Notícia dos usos e costumes dos povos de Timor". Anais do Conselho Ultramarino, Secção não oficial: 29-31.

- 1867. As possessões portuguezas da Oceânia. Lisboa: Imprensa $\mathrm{Na}$ cional.

CAStro, Gonçalo Pimenta de. 1944. Timor (subsídios para a sua história). Lisboa: Agência Geral das Colónias. COHN, Bernard S. 1985. "The command of language and the language of command". In: R. Guha (org.), Subaltern studies. IV. Delhi: Oxford University Press. pp. 276-329.

1996. Colonialism and its forms of knowledge. Princeton: Princeton University Press.

COLOMBIJN, Freek. 2003. "The volatile state in Southeast Asia: evidence from Sumatra, 1600-1800". The Journal of Asian Studies, 62(2):497-529.

COSTA, Luís. 2001. Dicionário de tetumportuguês. Lisboa: Colibri.

DALGADO, Sebastião Rodolfo. 1919. Glossário luso-asiático. 2 vols. Coimbra: Imprensa da Universidade.

DODSON, Michael S. 2005. "Translating science, translating empire: the power of language in colonial North India". Comparative Studies in Society and History, 47(4):809-835.

DORES, Raphael das. 1907. Diccionário de této-português. Lisboa: Imprensa Nacional.

FELGAS, Hélio. 1956. Timor português. Lisboa: Agência Geral do Ultramar. FORJAZ, Cypriano, para o Governador de Macau e Timor. 23 Nov. 1891. Lisboa: Arquivo Histórico Ultramarino, Ma- 
cau e Timor, ACL_SEMU_DGU_RM 003_Cx 6, 1887-1893.

FOUCAULT, Michel. 1971. L'ordre du discours. Paris: Gallimard.

FRANÇA, Bento da. 1897. Macau e os seus habitantes. Relações com Timor. Lisboa: Imprensa Nacional.

GOVERNO DE TIMOR, Termo lavrado a 26 de Fevereiro de 1880. Lisboa: Arquivo Histórico Ultramarino, Macau e Timor, ACL_SEMU_DGU_1R_002_Cx 1, 1879-1880.

GUSMÃO, Xanana. 1994. Timor Leste: um povo uma pátria. Lisboa: Colibri.

HANKS, William F. 2005. "Pierre Bourdieu and the practices of language". Annual Review of Anthropology, 34:67-83.

HOBSBAWM, Eric \& RANGER, Terence (orgs.). 1983. The invention of tradition. Cambridge: Cambridge University Press.

HOHE, Tanja \& NIXON, Rod. 2003. Reconciling justice. "Traditional" law and state judiciary in East Timor. United States Institute of Peace. Mimeo.

LACERDA, Hugo de, para o Governador de Macau e Timor. [x] Jan. 1875. Lisboa: Arquivo Histórico Ultramarino, Macau e Timor, ACL_SEMU_DGU_ RM_005_Cx 44, 1875.

MACHADO, José Pedro. 1989. Dicionário etimológico da língua portuguesa com a mais antiga documentação escrita e conhecida de muitos dos vocábulos estudados. Vol. 1. 5a. ed. Lisboa: Horizonte.

MARTINHO, José Simões. 1943. Timor. Quatro séculos de colonização portuguesa. Porto: Progredior.

McWILLIAM, Andrew. 2007. "Introduction: restorative custom: ethnographic perspectives on conflict and local justice in Timor". The Asia Pacific Journal of Anthropology, 8(1):1-8.

MERTZ, Elizabeth. 1994. "Legal language: pragmatics, poetics, and social power". Annual Review of Anthropology, 23:435-455.

O'HANLON, Rosalind \& WASHBROOK, David. 1992. "After orientalism: culture, criticism and politics in the Third World". Comparative Studies in Society and History, XXXIV(1):141-67.

PARRY, Benita. 2004. Postcolonial studies: a materialist critique. Londres: Routledge.

ROQUE, Ricardo \& WAGNER, Kim A. 2012.

"Introduction: engaging colonial knowledge". In: __. (orgs.), Engaging colonial knowledge: reading european archives in world history. Basingstoke: Palgrave Macmillan. pp. 1-32.

ROQUE, Ricardo. 2010. Headhunting and colonialism: anthropology and the circulation of human skulls in the Portuguese empire, 1870-1930. Basingstoke: Palgrave Macmillan.

. 2011a. "Etnografias coloniais, tecnologias miméticas: a administração colonial e os usos e costumes em Timor Leste no final do século XIX". In: K. Silva \& L. Sousa (orgs.), Ita Maun Alin... O livro do irmão mais novo. Afinidades antropológicas em Timor Leste. Lisboa: Colibri. pp. 155-168. . 2011b. "Os portugueses e os reinos de Timor no século XIX". Oriente, 20:91-111.

. 2012. "The Colonial Command of Ceremonial Language: Etiquette and Custom-Imitation in Nineteenth Century East Timor". In: L. Jarnagin (org.), Portuguese and Luso-Asian Legacies in Southeast Asia, 1511-2011. Vol. 2: Culture and Identity in the Luso-Asian World: Tenacities and Plasticities. 2 vols. Singapore: Institute of Southeast Asian Studies. pp. 67-87.

SAID, Edward. 1978. Orientalism: western conceptions of the Orient. New York: Pantheon. 
SCHULTE-NORDHOLT, H. 1971. The political system of the Atoni of Timor. The Hague: Nijhoff.

SILVA, António de Moraes. 1813. Diccionario da lingua portugueza. 2a. ed. Lisboa: Tip. Lacerdina.

SILVA, Celestino da, para Governador de Macau e Timor. [x] Aug. 1895. Lisboa: Arquivo Histórico Ultramarino, Macau e Timor, ACL_SEMU_DGU_2R_Cx 9, 1895-1896.

SILVA, Celestino da, para MNSMU (Ministro e Secretário dos Negócios da Marinha e Ultramar). 13 Julho 1905. Lisboa: Arquivo Histórico Ultramarino; Macau e Timor: ACL_SEMU_DGU_ RM_Pasta 3, 1904-1907.

SILVA, Celestino da, para MNSMU (Ministro e Secretário dos Negócios da Marinha e Ultramar). 11 Jan. 1898. Lisboa: Arquivo Histórico Ultramarino; Macau e Timor: ACL_SEMU_DGU_ 1R_003_Cx 10, 1897-1900.

SILVA, José Gomes da. 1892. "O combate de Ayassa". Boletim Oficial da Província de Macau e Timor, Suplemento 2:13-21.

SIMIÃO, Daniel Schroeder. 2011. "Sensibilidade jurídica e diversidade cultural: dilemas timorenses em perspectiva comparada". In: K. Silva e L. Sousa (orgs.), Ita Maun Alin... O livro do irmão mais novo. Afinidades antropológicas em Timor Leste. Lisboa: Colibri. pp. 113-129.

SOARES, Rogério. 2004. "Tara Bandu: the adat concept of the environment". East Timor Law Journal 12. Disponível em: http://easttimorlawjournal.wordpress. com/2012/05/19/tara-bandu-the-adatconcept-of-the-environment. Acesso em: 02 de janeiro 2012.

TAMBIAH, Stanley. 1977. "The galactic polity: the structure of traditional kingdoms in Southeast Asia". Annals of the New York Academy of Sciences, 293:69-97. Serie 1, Anthropology.
. 1985. "A performative approach to ritual". In: Culture, thought and social action: an anthropological perspective. Cambridge, Mass.: Harvard University Press. pp. 123-166.

VAQUINHAS, José dos Santos. 1884. "Timor. Usos - superstições de guerra". Boletim da Sociedade de Geografia de Lisboa, IV:476-492.

- 1885. "A pretendida usurpação do governo pelo revolucionário Varela, nos anos de 1869/70". Boletim da Sociedade de Geografia de Lisboa, $5^{\mathrm{a}}$ série, 1:61-64.

XAVIER, Filipe Nery. 1840-51. Collecção de bandos e outras differentes providencias que servem de leis regulamentares para o governo económico e judicial das Novas Conquistas, 1840-1851. 3 vols. Nova Goa: Imprensa Nacional.

YODER, Laura S. Meitzner. 2007. "Hybridising justice: state-customary interactions over forest crime and punishment in Oecusse, East Timor". The Asia Pacific Journal of Anthropology, 8(1):43-57.

YOUNG, Robert J. 2002. Postcolonialism: an historical introduction. Londres: Blackwell. 


\section{Resumo}

Este artigo examina as relações entre o discurso da justiça e a prática do ritual nos bandos do governo colonial português em Timor Leste, entre a segunda metade do século XIX e as primeiras décadas do século XX. Os bandos consistiam em ordens e instruções de comando emanadas pelo governador português em Díli, e comunicadas de forma cerimonial por oficiais às populações dos diversos reinos timorenses dispersos pelo país. Bandos eram um instrumento por excelência de governação colonial dos assuntos indígenas, servindo para arbitrar conflitos, punir transgressões e, em geral, instituir realidades no mundo timorense. Contudo, esta instituição assumiu igualmente uma singular expressão nos usos timorenses, servindo bandos para comunicar também as ordens de autoridades tradicionais, os liurais. $\mathrm{O}$ artigo acompanha as variações coloniais e indígenas que os bandos adquiriram em Timor Leste, conceptualizando-os enquanto colectivos de justiça. Ao considerar assim os bandos como colectivos - formações heterogéneas em que elementos linguísticos e não linguísticos se combinam na produção de efeitos de poder sobre as populações - o artigo propõe uma via conceptual alternativa às perspectivas linguísticas e literárias de análise do discurso colonial.

Palavras-chave Bandos, Discurso colonial, Justiça, Ritual, Timor Leste, História, Séculos XIX-XX.

\section{Abstract}

This article examines the relations between juridical discourse and ritual practice in the bandos issued by the Portuguese colonial government in East Timor between the second-half of the nineteenth century and the early decades of the twentieth century. Bandos consisted of orders and instructions of command issued by the Portuguese governor in Dilly and ceremonially transmitted by colonial officers to the populations of the various Timorese kingdoms. Bandos were a principal tool of colonial governance with regards to indigenous matters. They were used by the Portuguese to arbitrate conflicts, punish transgressions and, generally, to institute realities in the Timorese world. However, this institution also came to acquire a singular expression in the indigenous cultures, such that the Timorese traditional authorities, the liurais, also used it to communicate their own instructions and commands. The essay conceptualizes bandos as colectives of justice and explores their colonial and indigenous variants. In thus considering the bandos as collectives heterogeneous associations in which both linguistic and non-linguistic elements combine to produce power effects upon the populations - the article proposes a conceptual alternative to linguistic and literary perspectives in the analysis of colonial discourse.

Key words Bandos, Colonial Discourse, Justice, Ritual, East Timor, History, XIXthXXth Centuries. 